\title{
Decreased Expression of Breast Cancer Resistance Protein in the Duodenum in Patients with Obstructive Cholestasis
}

\author{
Christian Zimmermann ${ }^{a}$ Petr Hruz ${ }^{a, c}$ Heike Gutmann ${ }^{a}$ Luigi Terracciano $^{b}$ \\ Ulrich Beuers $^{d}$ Frank Lehmann $^{c}$ Christoph Beglinger ${ }^{c}$ Juergen Drewe ${ }^{a}$ \\ Departments of a Clinical Pharmacology and Toxicology, and ${ }^{b}$ Pathology, and ${ }^{\mathrm{c} D i v i s i o n}$ of Gastroenterology, \\ University Hospital of Basel, Basel, Switzerland; dDepartment of Medicine II, Klinikum Grosshadern, \\ Ludwig Maximilian University, Munich, Germany
}

\section{Key Words}

Breast cancer resistance protein $\mathrm{ABCG} 2 \cdot$ Transporter •

Cholestasis $\cdot$ Duodenum $\cdot$ Bile acids $\cdot$ Bilirubin

\begin{abstract}
Background/Aims: The expression of transporters involved in bile acid homeostasis is differentially regulated during obstructive cholestasis. Since the drug efflux transporter breast cancer resistance protein (BCRP) is known to transport bile acids, we investigated whether duodenal BCRP expression could be altered during cholestasis. Methods: Using realtime RT-PCR analysis we determined mRNA expression levels in duodenal tissue of 19 cholestatic patients. Expression levels were compared to 14 healthy subjects. BCRP protein staining was determined in biopsies of 6 cholestatic and 6 healthy subjects by immunohistochemistry. Results: We found that in patients with obstructive cholestasis mean duodenal BCRP mRNA levels were significantly reduced to $53 \%$ and mean protein staining was reduced to $57 \%$. Conclusions: $\mathrm{BCRP}$, a transporter for bile acids and numerous drugs, appears to be down-regulated in the human duodenum during cholestasis. The clinical impact of these results has to be investigated in further studies.
\end{abstract}

Copyright $\odot 2006$ S. Karger AG, Base

\section{KARGER}

Fax +41613061234 E-Mail karger@karger.ch www.karger.com
(C) 2006 S. Karger AG, Basel

0012-2823/06/0742-0101\$23.50/0

Accessible online at:

www.karger.com/dig

\section{Introduction}

The breast cancer resistance protein (BCRP/ABCG2) is a half-transporter that belongs to the G subfamily of ATP-binding cassette (ABC) transporters. Similar to Pglycoprotein, the product of the MDR1/ABCB1 gene, BCRP was detected and cloned from multi-drug resistant tumor cells [Doyle et al., 1998; Miyake et al., 1999]. Both efflux transporters are highly expressed in organs that play a protective role against toxic substances such as the intestine, the kidney, the liver, the blood brain barrier, and the placenta [Maliepaard et al., 2001]. In human jejunum, BCRP is even more expressed than P-glycoprotein [Taipalensuu et al., 2001]. BCRP mediates the translocation of various drugs like methotrexate, mitoxantrone, anthracyclines, $\mathrm{SN}-38$, and topotecan [Doyle et al., 1998; Volk and Schneider, 2003; Schellens et al., 2000]. It has further an essential role in extruding metabolites such as glucuronide and sulfate conjugates formed in enterocytes into the intestinal lumen [Adachi et al., 2005]. Moreover, BCRP protects the body from toxic constituents of food such as the carcinogen PhIP (2-amino-1methyl-6-phenylimidazo[4,5-b]pyridine) and the chlorophyll-derived phototoxin pheophorbide-a [van Herwaarden et al., 2003; Jonker et al., 2002]. In summary, its localization in the apical membrane of intestinal cells and

Juergen Drewe, MD, MSc

Department of Clinical Pharmacology and Toxicology

University Clinic Basel, Hebelstrasse 2

CH-4031 Basel (Switzerland)

Tel. +41 61265 3848, Fax +41 61265 8581, E-Mail juergen.drewe@unibas.ch 
Table 1. Biochemical parameters measured in control subjects and in patients with cholestasis

\begin{tabular}{lccc}
\hline Parameter & Controls & $\begin{array}{l}\text { Patients with } \\
\text { cholestasis }\end{array}$ & p value \\
\hline Bilirubin [5-26 $\mu \mathrm{mol} / \mathrm{l}]$ & $11.5(5.0-17.0)$ & $182.5(42-640)$ & $<0.001$ \\
ALAT [10-37 U/l] & $26.0(10-35)$ & $144(10-633)$ & $<0.003$ \\
ASAT [11-36 U/l] & $24.5(10-38)$ & $70.5(10-361)$ & $<0.002$ \\
$\gamma$-GT [11-66 U/l] & $59.0(45-68)$ & $449.5(74-1,510)$ & $<0.001$ \\
AP [43-106 U/l] & $71.0(44-84)$ & $257.0(100-1,855)$ & $<0.01$ \\
Total cholesterol [3-5.2 mmol/1] & $5.9(3.9-6.6)$ & $5.5(2.7-10.8)$ & $\mathrm{NS}$ \\
Bile acids [<10 $\mu \mathrm{mol} / \mathrm{l}]$ & $1.7(0.5-3.2)$ & $87.7(20.5-431.3)$ & $<0.001$ \\
\hline
\end{tabular}

Values are medians (range). The normal range is in square brackets. NS = Statistically not significant. its wide substrate specificity suggests that BCRP is an important transporter limiting the absorption of orally administered drugs and ingested toxins.

Most members of the ABCG subfamily are involved in the translocation of endogenous compounds. ABCG1 is supposed to be a regulator of cholesterol and phospholipid transport [Klucken et al., 2000], whereas the heterodimeric proteins ABCG5/ABCG8 promote biliary excretion and limit intestinal absorption of neutral sterols [Yu et al., 2002]. It was shown that BCRP can also transport endogenous substrates such as sulphated steroids [Imai et al., 2005; Suzuki et al., 2003] and primary bile acids [Janvilisri et al., 2005]. The precise physiological role of BCRP remains, however, to be defined.

The fact that BCRP is capable of transporting bile acids may indicate that this transporter is involved in bile acid homeostasis. As an efflux pump, it could protect the enterocytes from potential toxic bile acid concentrations. During cholestasis, in which the enterohepatic circulation is disrupted, an adaptive regulation of transporters for bile acids, bilirubin and cholesterol occurs [Kamisako and Ogawa, 2005; Tanaka et al., 2002; Zollner et al., 2003; Denk et al., 2004]. These changes take place in the liver, the kidney, as well as in the intestine. We have recently shown that the responsible gene for bile acid reuptake in the intestine, the apical sodium dependent bile acid transporter (ASBT), is down-regulated in cholestatic patients [Hruz et al., 2006].

Here we have analyzed the duodenal expression of BCRP in patients with obstructive cholestasis. The disease is associated with elevated bile acid levels in serum, a lack of bile acids in the intestinal lumen, and increase in proinflammatory cytokines [Plebani et al., 1999]. We hypothesized that BCRP, as a potential bile acid transporter, could show an altered gene expression during ob- structive cholestasis. Indeed, we can show that cholestatic patients exhibit decreased BCRP expression in the intestine compared to healthy subjects. Further studies are necessary to characterize the impact of these results on the pharmacokinetics of drugs and the exposure to dietary toxins that are BCRP substrates.

\section{Materials and Methods}

\section{Patients}

Fourteen healthy subjects ( 7 females, 7 males) and 19 cholestatic patients ( 10 females, 9 males) were enrolled in the study after giving informed consent. The group of control subjects had a mean age of 59.8 (43-75) years and cholestatic patients 67.5 (4185 ) years. Biochemical parameters of both groups are displayed in table 1 . The control subjects had an indication for a gastrointestinal tract endoscopy within a cancer-screening program, whereas patients with obstructive cholestasis had an interventional endoscopic retrograde cholangiopancreatography (ERCP). Within the cholestatic group, nine patients had obstructive tumors (3 carcinoma of the pancreatic head, 4 cholangiocarcinoma (Klatskin tumor) and two metastatic diseases). 10 patients had benign diseases ( 8 patients with choledocholithiasis and 2 patients with benign stenosis of the common bile duct). Patients had no clinical signs of cholangitis. Shortly before endoscopic intervention patients undergoing ERCP received $4 \mathrm{~g}$ piperacillin $/ 0.5 \mathrm{~g}$ tazobactam. Patients taking medication which is known to induce drug transporters were excluded from the study.

Obstructive jaundice was defined on the basis of chemical parameters (bilirubin, $\gamma$-glutamyltransferase, and alkaline phosphatase) and on imaging procedures (ultrasound and ERCP) demonstrating a dilated bile duct system. All control patients had normal values of the above mentioned parameters. During endoscopy four biopsy specimens were obtained from the distal part of the duodenum. Biopsies were immediately stored at $-70^{\circ} \mathrm{C}$ until further processing. The study was approved by the State Ethical Committee of Basel (Ethische Kommission beider Basel, EKBB) and recorded in the clinical trial register of the United States National Library of Medicine (ID: NTC00295360). 
Table 2. Sequences of PCR primers used for generating the cDNA standards and of TaqMan primers/probes used for real-time PCR

\begin{tabular}{|c|c|}
\hline \multicolumn{2}{|l|}{$B C R P$} \\
\hline PCR primer forward & 5'-TTTCAGCCGTGGAACTCTTT-3' \\
\hline PCR primer reverse & 5'-TGAGTCCTGGGCAGAAGTTT-3' \\
\hline TaqMan primer forward & 5'-CAGGTCTGTTGGTCAATCTCACA-3' \\
\hline TaqMan probe & 5'-CCATTGCATCTTGGCTGTCATGGCTT-3' \\
\hline TaqMan primer reverse & 5'-TCCATATCGTGGAATGCTGAAG-3' \\
\hline \multicolumn{2}{|l|}{ Villin } \\
\hline PCR primer forward & 5'-AGAAAGCCAATGAGCAGGAGAA-3' \\
\hline PCR primer reverse & 5'-ATGGATGTGGCATCGAACTTC-3' \\
\hline TaqMan primer forward & 5'-CATGAGCCATGCGCTGAAC-3' \\
\hline TaqMan probe & 5'-TCATCAAAGCCAAGCAGTACCCACCAAG-3' \\
\hline TaqMan primer reverse & 5'-TCATTCTGCACCTCCACCTGT-3' \\
\hline
\end{tabular}

Real-Time RT-PCR Analysis (TaqMan)

Total RNA was isolated from 2 biopsies from each subject. RNA was extracted using the RNeasy Mini Kit (Qiagen $\mathrm{GmbH}$, Hilden, Germany) following the instructions provided by the manufacturer. RNA was quantified with a GeneQuant photometer (Pharmacia, Uppsala, Sweden). After DNase I digestion (Gibco, Life Technologies, Basel Switzerland) $1.5 \mu \mathrm{g}$ of total RNA was reverse-transcribed by Superscript (Gibco Life Technologies) according to the manufacturer's protocol using random hexamers as primers.

TaqMan analysis was carried out on a 7900HT Sequence Detection System (Applied Biosystems, Rotkreuz, Switzerland) as previously described in recent papers of our group [Hruz et al., 2006; Zimmermann et al., 2005; Gutmann et al., 2005]. In brief, the standards we used for mRNA quantification were obtained by classical PCR using duodenal cDNA as a template. Primers for generating the standards and primers/probes for TaqMan analysis were designed according to the guidelines of Applied Biosystems with the help of the Primer Express 2.0 software (corresponding sequences are displayed in table 2). All samples were run in triplicates and were quantified using a standard curve. Not reverse-transcribed RNA served as a negative control. For each sample the transcript numbers of BCRP and of villin were determined. By calculating the ratio BCRP/villin, the mRNA expression was normalized. This approach has been established to account for variations in the enterocyte content of biopsies [Taipalensuu et al., 2001; Lown et al., 1997].

\section{Immunohistochemistry}

Human duodenal tissue fragments were mounted in OCT compound (Sakura Finetek, Zooterwoude, The Netherlands), snap frozen in liquid nitrogen and stored at $-70^{\circ} \mathrm{C}$. Frozen sections $(5 \mu \mathrm{m})$ were then air dried overnight and a periodate-lysine paraformaldehyde solution (3\%) was used for postfixation. Then the sections were washed with washing solution $(\mathrm{TBS} / \mathrm{NaCl}$, Tween $0.05 \%$ ) and incubated with normal horse serum for $30 \mathrm{~min}$ at room temperature as blocking solution. The tissue sections were incubated with a 1:40 dilution of the BCRP monoclonal antibody BXP-21 (Alexis Biochemicals, Lausen, Switzerland) overnight at $4^{\circ} \mathrm{C}$. Samples were washed three times with washing solution and incubated with the horse antimouse IgG secondary antibody for $30 \mathrm{~min}$ at room temperature. After three washes with the washing solution, a perhydral solution $\left(\mathrm{H}_{2} \mathrm{O}_{2}(0.3 \%)\right.$, sodium azide $(0.1 \%)$ in $\mathrm{PBS}$ ) was used to destroy the endogenous peroxidase activity. The staining was performed with the avidin/ biotinylated enzyme complex (ABC method) according to the manufacturer's instructions (Vectastain, Elite kit, Vector Laboratories, Burlingame, Calif., USA). For detection 3-amino-9-ethylcarbazole (AEC), which forms a red end product, was used (Biogenex, San Ramon, Calif., USA). Sections, which served as negative controls, were treated equally except that they were not incubated with the primary antibody. Semiquantitative analysis of BCRP staining in biopsies of 6 control subjects and 6 cholestatic patients was done by a trained pathologist by assessing protein staining on blinded specimens. Expression levels were rated as follows: $0=$ no expression, $1=$ low, $2=$ intermediate, $3=$ high expression.

\section{Bile Acid and Bilirubin Plasma Concentrations}

Blood samples from all subjects were obtained shortly before endoscopic procedure. Fasting plasma levels of bile acids were determined as described previously by our group [Hruz et al., 2006] using the method of Stellaard et al. [1984]. Bilirubin plasma concentrations were measured by a modified Malloy-Evelyn method (BIL-T, Roche Diagnostics, Mannheim, Germany).

\section{Statistics}

All values were expressed as means \pm SEM. Icteric patient's BCRP expression was compared to that of healthy controls by analysis of variance (ANOVA). All comparisons were performed as two-sided comparisons using the SPSS for Windows software (version 14.0). Level of significance was $\mathrm{p}<0.05$.

\section{Results}

\section{BCRP mRNA Expression Is Down-Regulated during Cholestasis}

Duodenal mRNA expression of BCRP and villin was analyzed in 14 healthy subjects and 19 patients with obstructive cholestasis. In cholestatic patients mean BCRP mRNA levels were reduced to $53.6 \%$ when compared to 
Fig. 1. Comparison of BCRP expression in healthy subjects versus cholestatic patients (mean \pm SEM). a Expression of BCRP $\mathrm{mRNA}$ relative to villin (14 controls versus 19 cholestatic patients). b BCRP protein expression using immunohistochemical staining with semi-quantitative analysis (6 controls vs. 6 cholestatic patients).

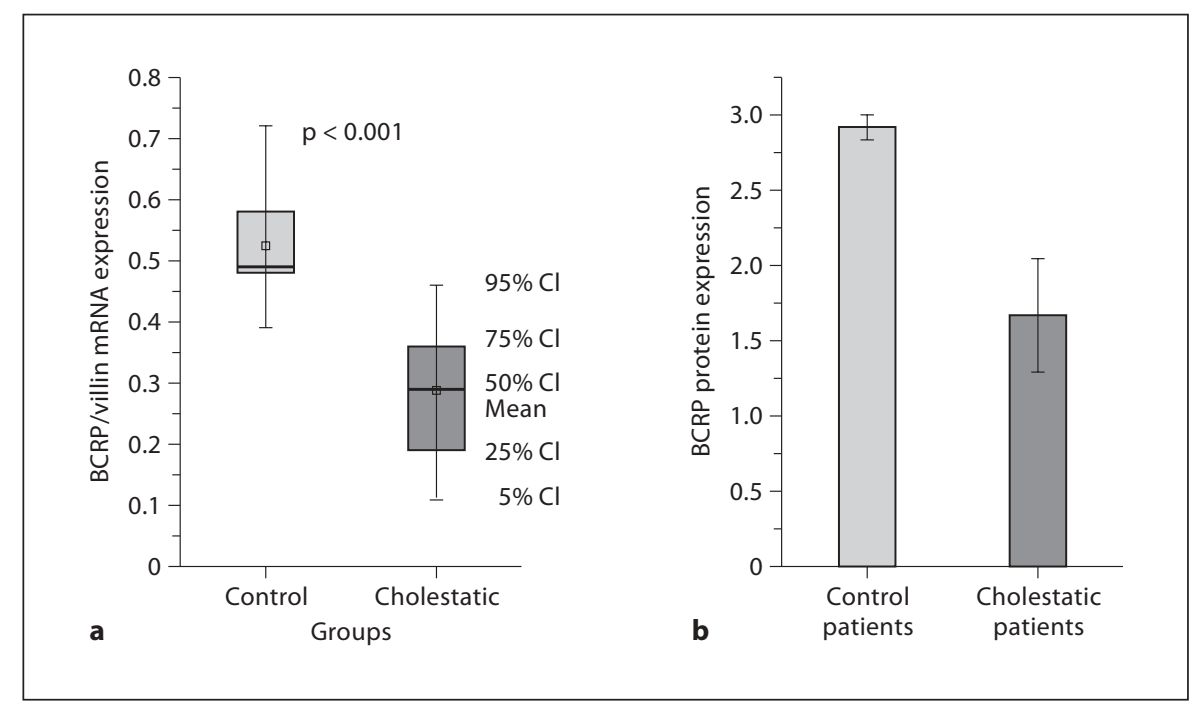

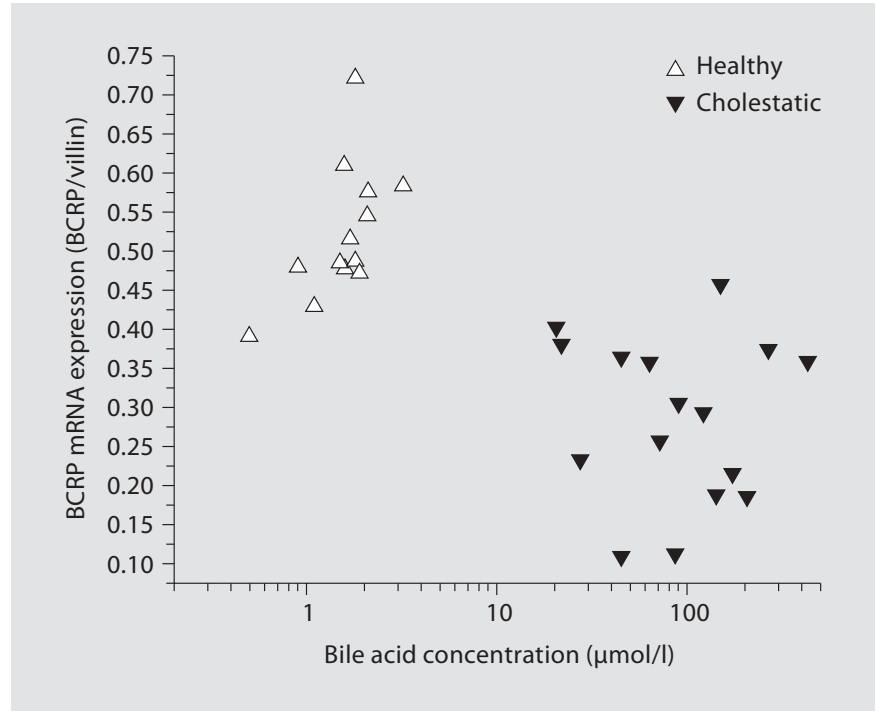

Fig. 2. Individual BCRP mRNA expression (BCRP/villin) in 13 healthy subjects and 16 cholestatic patients. BCRP mRNA expression is shown in correlation to bile acid serum concentration.

healthy subjects. Relative expression (mean BCRP/villin \pm SEM) was $0.51( \pm 0.03)$ in controls and $0.27( \pm 0.02)$ in cholestatic patients $(\mathrm{p}<0.001)$ (fig. 1a). Mean villin mRNA expression was not significantly different between the control and cholestatic groups (data not shown). Figure 2 displays the individual BCRP mRNA expression in correlation to bile acid serum concentration (fig. 2a) and bilirubin serum concentration (fig. 2b).
Patients with cholestasis due to tumor or biliary stones did not differ in their BCRP expression: on average, this amounted to $0.26 \pm 0.038(\mathrm{SEM}), \mathrm{n}=9$ and $0.28 \pm$ $0.031, \mathrm{n}=10$. This difference was not statistically significant.

\section{BCRP Protein Levels Are Decreased in Cholestatic \\ Patients}

BCRP protein expression was evaluated by immunohistochemistry in 6 control subjects and 6 patients with cholestasis. BCRP protein was expressed on the apical membrane of the duodenal epithelial cells. Representative pictures of duodenal tissues are displayed in figure $3 a$ (healthy subject) and figure $3 b$ (cholestatic patient). Expression levels were rated as follows: $0=$ no expression, 1 = low, 2 = intermediate, 3 = high expression. In patients with obstructive cholestasis mean BCRP protein levels were reduced to $57.1 \%$ when compared to healthy subjects. Protein expression (mean \pm SEM) was 2.91 ( \pm $0.08)$ in control subjects and $1.67( \pm 0.38)$ in cholestatic patients $(\mathrm{p}<0.005)$ (fig. $1 \mathrm{~b})$.

Correlation of BCRP mRNA Expression with Age and Body Mass Index

Age was not significantly $\left(\mathrm{p}=0.14 ; \mathrm{R}^{2}=-0.26\right)$ correlated with BCRP mRNA expression. However, there was a statistically significant $(\mathrm{p}=0.041)$ positive although weak $\left(\mathrm{R}^{2}=0.36\right)$ correlation body mass index with BCRP mRNA expression. 

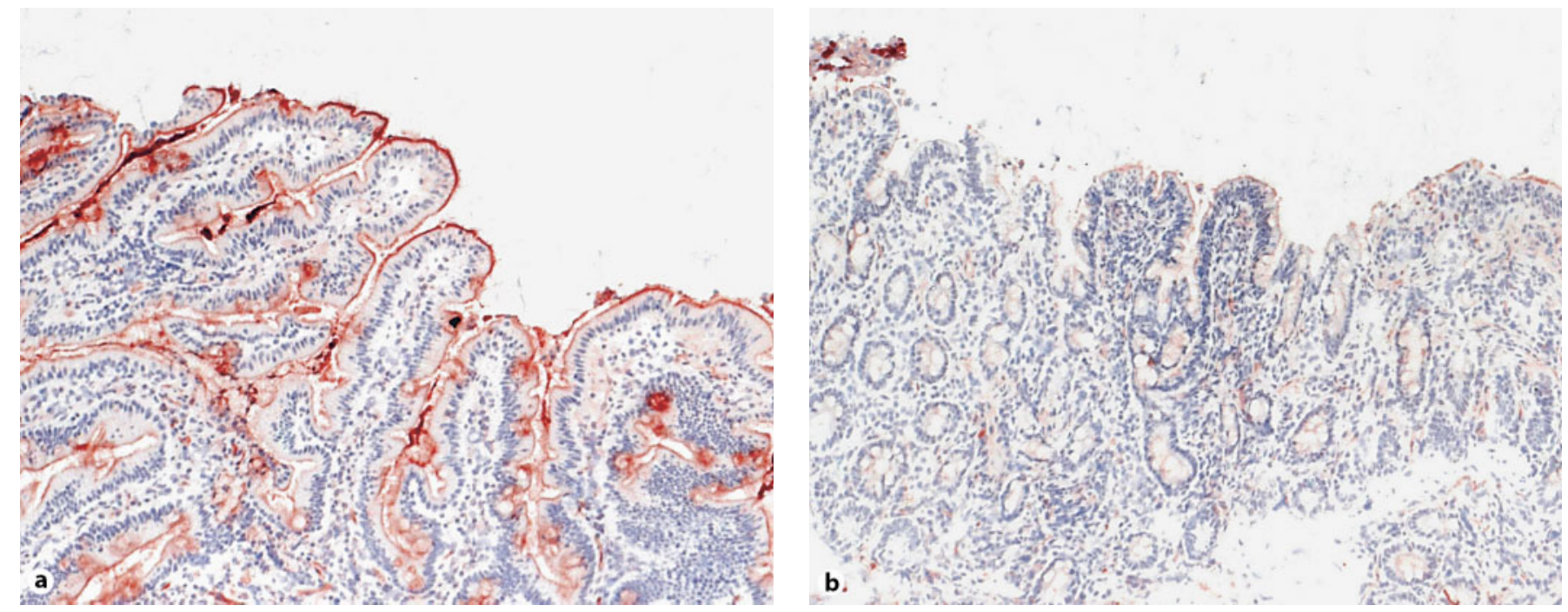

Fig. 3. Immunohistochemical staining of BCRP protein on the apical membrane of human duodenal epithelial cells using the BCRP antibody BXP-21. a Clear staining of BCRP protein in a duodenal sample from a healthy subject. b Reduced staining in a duodenal sample of a patient with obstructive cholestasis. Both pictures are at 200 -fold magnification.

\section{Effect of Reconstitution of Bile Flow on BCRP mRNA Expression}

In 4 patients, a follow-up gastroscopy could be performed 10-40 weeks after reconstitution of bile flow (data not shown). A follow-up endoscopy was only performed when medically indicated. Two of the 4 patients received stents into the common bile duct due to a biliary stone, 1 patient had a Whipple operation due to tumor of the pancreas head and one due to cholangiocarcinoma.

These patients showed normalized bile acid and bilirubin plasma levels at the time when duodenal follow-up biopsies were taken. In 3 patients the BCRP mRNA expression increased (1.44-, 1.71-, and 1.90-fold) when compared to the expression level of cholestasis. In one patient, the level did not change clinically significantly (1.05-fold increase). This patient suffered from choledocholithiasis, had low initial bilirubin $(65 \mu \mathrm{mol} / \mathrm{l})$ as well as bile acid ( $44.7 \mu \mathrm{mol} / \mathrm{l})$ plasma levels and was the patient with the shortest interval to follow-up endoscopy (10 weeks).

\section{Discussion}

Our data demonstrate that during complete or near complete obstruction of the bile duct by a tumor or biliary stone intestinal BCRP expression is down-regulated on the transcriptional level leading to reduced amount of BCRP protein.

At the moment, little is known about the transcriptional regulation of this transporter. Only recently, an estrogen response element in the BCRP promotor was discovered [Ee et al., 2004]. Tanaka et al. [2005] observed, however, a higher BCRP expression in the kidney and liver of male rats and male mice, respectively. Furthermore, it has been reported that estrogens down-regulate BCRP protein expression by posttranscriptional mechanisms [Imai et al., 2005]. Recently, we have analyzed BCRP mRNA expression along the human gastrointestinal tract of healthy subjects with respect to sex [Gutmann et al., 2005]. No sex-related differences were observed. The data of the present study again show no significant differences between women and men (data not shown). We infer from these data that sexual hormones have most probably no effect on the expression of BCRP in the human intestine.

This is the first study demonstrating that the expression of BCRP is altered in the human intestine during disease. Our results are in conflict with another study, where no differences in duodenal BCRP protein levels were observed between icteric patients and healthy subjects [Dietrich et al., 2004a]. The authors analyzed the expression of several ABC transporters including BCRP in the human intestine and found only MRP2 to be down- 
regulated. A possible explanation for this discrepancy could be different durations and/or severity of cholestasis between the two patient groups. Although the duration of cholestasis is not known in both studies, the patients in our study exhibited a higher mean level of bilirubin ( $235 \mathrm{vs} .174 \mu \mathrm{mol} / \mathrm{l})$, which could indicate a higher severity of cholestasis.

During cholestasis, the expression of bile acid and bilirubin transporters such as the ABC-transporters MRP2, MRP3, MRP4, and organic anion transporting polypeptides (OATPs) is significantly changed [Tanaka et al., 2002; Denk et al., 2004; Dietrich et al., 2004a; Wagner et al., 2003]. Alterations in transporter expression do not only occur in the liver but also in remote organs such as the kidney and intestine. The systemic mediators that regulate these events during cholestasis have not been fully discovered. Proinflammatory cytokines, bile salts, or hormones have been suggested to control transporter gene expression [Trauner et al., 2005].

IL-1 $\beta$ has been identified as the central mediator for the down-regulation of intestinal and hepatic MRP2 [Dietrich et al., 2004a; Denson et al., 2002]. TNF- $\alpha$ and IL-1 $\beta$ are responsible for the down-regulation of several other hepatobiliary transporters [Geier et al., 2003]. Cytokines mediate these effects by reducing the binding activity of nuclear receptors to the corresponding promoters [Denson et al., 2002; Geier et al., 2003; Li and Klaassen, 2004]. Bile acids, on the other hand, act through binding to their endogenous receptor farnesoid X receptor (FXR), which induces the expression of small heterodimer partner (SHP) [Lu et al., 2000]. SHP in turn represses the expression of several genes involved in bile acid homeostasis [Jung and Kullak-Ublick, 2003; Popowski et al., 2005]. PXR is a further transcription factor that can be activated by bile acids [Xie et al., 2001]. PXR activation leads to the induction of multiple detoxification pathways including transporters [Stedman et al., 2005]. Moreover, hormones like glucocorticoids can influence transporter expression, as they are able to transactivate the intestinal bile acid transporter ASBT via the glucocorticoid receptor [Jung et al., 2004]. However, until now, there are no indications that intestinal BCRP could also be regulated by the above-mentioned mechanisms, though members of the ABCG subfamily such as ABCG1 and ABCG5/ABCG8 are repressed by bile acids via the FXR-SHP pathway in vitro [Freeman et al., 2004; Brendel et al., 2002]. This demonstrates that further investigations concerning BCRP regulation are required.

In the state of obstructive cholestasis, virtually no bile acids are present in the intestinal lumen. If BCRP medi- ates the efflux of bile salts that entered the enterocyte from the lumen, a down-regulation of this transporter could reflect an adaptive regulation during cholestasis. On the other hand, as BCRP is a potent efflux pump for a variety of toxic compounds, a diminished expression could weaken the intestinal barrier and the excretory function of the gut. In this respect, Dietrich et al. [2004b] determined the elimination of the dietary carcinogen PhIP in bile duct ligated rats. They demonstrated that the excretion of this toxin was significantly reduced in parallel with a decreased expression of MRP2 and BCRP in liver. Furthermore, tissue binding of reactive metabolites was increased in liver and colon. A reduced intestinal BCRP expression could substantially contribute to the accumulation of carcinogens in enterocytes. This in turn might partly explain the observation that patients with primary sclerosing cholangiitis, a chronic cholestatic disease, have a higher risk of developing colorectal carcinoma [Broome et al., 1995]. However, many patients with primary sclerosing cholangiitis have an associated ulcerative colitis, which per se represents a kind of precancerous state [Smith and Loe, 1965].

In conclusion, we showed that patients with obstructive cholestasis exhibit a decreased expression of BCRP on mRNA and protein level. A decreased expression of this efflux pump might increase the accumulation of food-derived carcinogens and influence the pharmacokinetics of various anticancer drugs. However, the reduced expression of a certain transport protein may not be predictive for the impaired intestinal extrusion of a certain substrate. To evaluate potential clinical implications of these findings, further studies are needed.

\section{Acknowledgments}

We are very thankful to Uschi Behrens, Ursula Dürrmüller and Gudrun Schwertfeger for their excellent technical assistance. 


\section{References}

Adachi Y, Suzuki H, Schinkel AH, Sugiyama Y: Role of breast cancer resistance protein (Bcrp1/Abcg2) in the extrusion of glucuronide and sulfate conjugates from enterocytes to intestinal lumen. Mol Pharmacol 2005;67: 923-928.

Brendel C, Schoonjans K, Botrugno OA, Treuter E, Auwerx J: The small heterodimer partner interacts with the liver $\mathrm{X}$ receptor alpha and represses its transcriptional activity. Mol Endocrinol 2002;16:2065-2076.

Broome U, Lofberg R, Veress B, Eriksson LS: Primary sclerosing cholangiitis and ulcerative colitis: evidence for increased neoplastic potential. Hepatology 1995;22:1404-1408.

Denk GU, Soroka CJ, Takeyama Y, Chen WS, Schuetz JD, Boyer JL: Multidrug resistanceassociated protein 4 is up-regulated in liver but down-regulated in kidney in obstructive cholestasis in the rat. J Hepatol 2004;40:585591.

Denson LA, Bohan A, Held MA, Boyer JL: Organ-specific alterations in RAR alpha:RXR alpha abundance regulate rat Mrp2 (Abcc2) expression in obstructive cholestasis. Gastroenterology 2002;123:599-607.

Dietrich CG, Geier A, Salein N, Lammert F, Roeb E, Oude Elferink RP, Matern S, Gartung C: Consequences of bile duct obstruction on intestinal expression and function of multidrug resistance-associated protein 2 . Gastroenterology 2004a;126:1044-1053.

Dietrich CG, Geier A, Wasmuth HE, Matern S, Gartung C, de Waart DR, Elferink RP: Influence of biliary cirrhosis on the detoxification and elimination of a food derived carcinogen. Gut 2004b;53:1850-1855.

Doyle LA, Yang W, Abruzzo LV, Krogmann T, Gao Y, Rishi AK, Ross DD: A multidrug resistance transporter from human MCF-7 breast cancer cells. Proc Natl Acad Sci USA 1998;95:15665-15670.

Ee PL, Kamalakaran S, Tonetti D, He X, Ross DD, Beck WT: Identification of a novel estrogen response element in the breast cancer resistance protein (ABCG2) gene. Cancer Res 2004;64:1247-1251.

Freeman LA, Kennedy A, Wu J, Bark S, Remaley AT, Santamarina-Fojo S, Brewer HB Jr: The orphan nuclear receptor LRH-1 activates the ABCG5/ABCG8 intergenic promoter. J Lipid Res 2004;45:1197-1206.

Geier A, Dietrich CG, Voigt S, Kim SK, Gerloff T, Kullak-Ublick GA, Lorenzen J, Matern S, Gartung C: Effects of proinflammatory cytokines on rat organic anion transporters during toxic liver injury and cholestasis. Hepatology 2003;38:345-354.

Gutmann H, Hruz P, Zimmermann C, Beglinger C, Drewe J: Distribution of breast cancer resistance protein (BCRP/ABCG2) mRNA expression along the human GI tract. Biochem Pharmacol 2005;70:695-699.
Hruz P, Zimmermann C, Gutmann H, Degen L, Beuers U, Terracciano L, Drewe J, Beglinger C: Adaptive regulation of the ileal apical sodium dependent bile acid transporter (ASBT) in patients with obstructive cholestasis. Gut 2006;55:395-402.

Imai Y, Ishikawa E, Asada S, Sugimoto Y: Estrogen-mediated post transcriptional downregulation of breast cancer resistance protein/ABCG2. Cancer Res 2005;65:596-604.

Janvilisri T, Shahi S, Venter H, Balakrishnan L, van Veen HW: Arginine-482 is not essential for transport of antibiotics, primary bile acids and unconjugated sterols by the human breast cancer resistance protein (ABCG2). Biochem J 2005;385:419-426.

Jonker JW, Buitelaar M, Wagenaar E, Van Der Valk MA, Scheffer GL, Scheper RJ, Plosch T, Kuipers F, Elferink RP, Rosing H, Beijnen JH, Schinkel AH: The breast cancer resistance protein protects against a major chlorophyllderived dietary phototoxin and protoporphyria. Proc Natl Acad Sci USA 2002;99: 15649-15654.

Jung D, Fantin AC, Scheurer U, Fried M, KullakUblick GA: Human ileal bile acid transporter gene ASBT (SLC10A2) is transactivated by the glucocorticoid receptor. Gut 2004;53: 78-84.

Jung D, Kullak-Ublick GA: Hepatocyte nuclear factor 1 alpha: a key mediator of the effect of bile acids on gene expression. Hepatology 2003;37:622-631.

Kamisako T, Ogawa H: Alteration of the expression of adenosine triphosphate-binding cassette transporters associated with bile acid and cholesterol transport in the rat liver and intestine during cholestasis. J Gastroenterol Hepatol 2005;20:1429-1434.

Klucken J, Buchler C, Orso E, Kaminski WE, Porsch-Ozcurumez M, Liebisch G, Kapinsky M, Diederich W, Drobnik W, Dean M, Allikmets R, Schmitz G: ABCG1 (ABC8), the human homolog of the Drosophila white gene, is a regulator of macrophage cholesterol and phospholipid transport. Proc Natl Acad Sci USA 2000;97:817-822.

Li N, Klaassen CD: Role of liver-enriched transcription factors in the down-regulation of organic anion transporting polypeptide 4 (oatp4; oatplb2; slc21a10) by lipopolysaccharide. Mol Pharmacol 2004;66:694-701.

Lown KS, Bailey DG, Fontana RJ, Janardan SK, Adair CH, Fortlage LA, Brown MB, Guo W, Watkins PB: Grapefruit juice increases felodipine oral availability in humans by decreasing intestinal CYP3A protein expression. J Clin Invest 1997;99:2545-2553.

Lu TT, Makishima M, Repa JJ, Schoonjans K, Kerr TA, Auwerx J, Mangelsdorf DJ: Molecular basis for feedback regulation of bile acid synthesis by nuclear receptors. Mol Cell 2000;6:507-515.
Maliepaard M, Scheffer GL, Faneyte IF, van Gastelen MA, Pijnenborg AC, Schinkel AH, van De Vijver MJ, Scheper RJ, Schellens JH: Subcellular localization and distribution of the breast cancer resistance protein transporter in normal human tissues. Cancer Res 2001; 61:3458-3464.

Miyake K, Mickley L, Litman T, Zhan Z, Robey R, Cristensen B, Brangi M, Greenberger L, Dean M, Fojo T, Bates SE: Molecular cloning of cDNAs which are highly overexpressed in mitoxantrone-resistant cells: demonstration of homology to $\mathrm{ABC}$ transport genes. Cancer Res 1999;59:8-13.

Plebani M, Panozzo MP, Basso D, De Paoli M, Biasin R, Infantolino D: Cytokines and the progression of liver damage in experimental bile duct ligation. Clin Exp Pharmacol Physiol 1999;26:358-363.

Popowski K, Eloranta JJ, Saborowski M, Fried M, Meier PJ, Kullak-Ublick GA: The human organic anion transporter 2 gene is transactivated by hepatocyte nuclear factor- 4 alpha and suppressed by bile acids. Mol Pharmacol 2005;67:1629-1638.

Schellens JH, Maliepaard M, Scheper RJ, Scheffer GL, Jonker JW, Smit JW, Beijnen JH, Schinkel AH: Transport of topoisomerase I inhibitors by the breast cancer resistance protein: potential clinical implications. Ann NY Acad Sci 2000;922:188-194.

Smith M, Loe S: Sclerosing cholangiitis: review of recent case reports and associated diseases and four new cases. Am J Surg 1965;110:239246

Stedman CA, Liddle C, Coulter SA, Sonoda J, Alvarez JG, Moore DD, Evans RM, Downes M: Nuclear receptors constitutive androstane receptor and pregnane $\mathrm{X}$ receptor ameliorate cholestatic liver injury. Proc Natl Acad Sci USA 2005;102:2063-2068.

Stellaard F, Sackmann M, Sauerbruch T, Paumgartner G: Simultaneous determination of cholic acid and chenodeoxycholic acid pool sizes and fractional turnover rates in human serum using ${ }^{13} \mathrm{C}$-labeled bile acids. J Lipid Res 1984;25:1313-1319.

Suzuki M, Suzuki H, Sugimoto Y, Sugiyama Y: ABCG2 transports sulfated conjugates of steroids and xenobiotics. J Biol Chem 2003; 278:22644-22649.

Taipalensuu J, Tornblom H, Lindberg G, Einarsson C, Sjoqvist F, Melhus H, Garberg P, Sjostrom B, Lundgren B, Artursson P: Correlation of gene expression of ten drug efflux proteins of the ATP-binding cassette transporter family in normal human jejunum and in human intestinal epithelial Caco-2 cell monolayers. J Pharmacol Exp Ther 2001;299: 164-170. 
Tanaka Y, Kobayashi Y, Gabazza EC, Higuchi K, Kamisako T, Kuroda M, Takeuchi K, Iwasa M, Kaito M, Adachi Y: Increased renal expression of bilirubin glucuronide transporters in a rat model of obstructive jaundice. Am J Physiol Gastrointest Liver Physiol 2002;282:G656-G662.

Tanaka Y, Slitt AL, Leazer TM, Maher JM, Klaassen CD: Tissue distribution and hormonal regulation of the breast cancer resistance protein (Bcrp/Abcg2) in rats and mice. Biochem Biophys Res Commun 2005;326:181187.

Trauner M, Wagner M, Fickert P, Zollner G: Molecular regulation of hepatobiliary transport systems: clinical implications for understanding and treating cholestasis. J Clin Gastroenterol 2005;39:S111-S124. van Herwaarden AE, Jonker JW, Wagenaar E, Brinkhuis RF, Schellens JH, Beijnen JH, Schinkel AH: The breast cancer resistance protein (Bcrp1/Abcg2) restricts exposure to the dietary carcinogen 2-amino-1-methyl-6phenylimidazo[4,5-b]pyridine. Cancer Res 2003;63:6447-6452.

Volk EL, Schneider E: Wild-type breast cancer resistance protein (BCRP/ABCG2) is a methotrexate polyglutamate transporter. Cancer Res 2003;63:5538-5543.

Wagner M, Fickert P, Zollner G, Fuchsbichler A Silbert D, Tsybrovskyy O, Zatloukal K, Guo GL, Schuetz JD, Gonzalez FJ, Marschall HU, Denk H, Trauner M: Role of farnesoid X receptor in determining hepatic $\mathrm{ABC}$ transporter expression and liver injury in bile duct-ligated mice. Gastroenterology 2003; 125:825-838.

Xie W, Radominska-Pandya A, Shi Y, Simon CM, Nelson MC, Ong ES, Waxman DJ, Evans RM: An essential role for nuclear receptors SXR/PXR in detoxification of cholestatic bile acids. Proc Natl Acad Sci USA 2001;98: 3375-3380.
Yu L, Li-Hawkins J, Hammer RE, Berge KE, Horton JD, Cohen JC, Hobbs HH: Overexpression of ABCG5 and ABCG8 promotes biliary cholesterol secretion and reduces fractional absorption of dietary cholesterol. J Clin Invest 2002;110:671-680.

Zimmermann C, Gutmann H, Hruz P, Gutzwiller JP, Beglinger C, Drewe J: Mapping of multidrug resistance gene 1 and multidrug resistance-associated protein isoform 1 to 5 mRNA expression along the human intestinal tract. Drug Metab Dispos 2005;33:219224.

Zollner G, Fickert P, Silbert D, Fuchsbichler A, Marschall HU, Zatloukal K, Denk H, Trauner M: Adaptive changes in hepatobiliary transporter expression in primary biliary cirrhosis. J Hepatol 2003;38:717-727. 